\title{
NAUTICAL TOURISM AND REGIONAL POPULATION: THE ITALIAN CASE
}

\author{
FRANCESCO RUSSO \& CORRADO RINDONE \\ Department of Information Engineering, Infrastructure and Sustainable Energy, \\ University of Mediterranean Studies of Reggio Calabria, Italy
}

\begin{abstract}
Nautical tourism is a complex system comprehending different transport components (infrastructures, services and demand). Touristic ports represent a primary facility to perform nautical tourism activities. Despite its relevance, nautical tourism is an under-exploited research area. Information on demand and supply (infrastructures and services) is needed in order to support maritime planning. The main objective of the paper is to analyse the main data and quantitative linking between nautical tourism variables and regional population. The focus is on the specific case study of Italian regions. In order to reach the objective, the paper investigates different data sources relative to nautical tourism in Italy. A classification of available variables is performed in relation to transport system components and in relation to the level of territorial regional aggregation. The paper presents a first step of research on nautical tourism. Available data sources focused in this paper represent a starting point of a transport planning process supported by quantitative analyses. In fact, obtained results show some characteristics of the current situation but further developments are needed.
\end{abstract}

Keywords: nautical tourism, touristic ports, transport planning, supply and demand variables.

\section{INTRODUCTION}

Maritime mobility includes two specific market segments: freight and people. Freight maritime mobility includes shipping on deep sea routes [1] and short-sea shipping [2]. People maritime mobility includes traveling for business and for leisure and tourism. This paper focuses on tourism, including activities like sailing and recreational boating, commonly named nautical tourism differentiating from cruise tourism.

Nautical tourism is a subset of coastal and maritime tourism, representing an intersection set among the three economic sectors: transport, tourism, and recreation [3]. At European level, coastal and maritime tourism generates a total of $€ 183$ billion in gross value added and representing over one third of the maritime economy [4]. Considering the relevance of this sector, the European Commission has defined a European strategy for more growth and jobs in coastal and maritime tourism (the CMT strategy) [5]. The strategy proposes a set of actions to be undertaken at European, national and regional levels, in order to satisfy the needs and challenges of the sector.

With about 7,500 km of coastlines, that is $23 \%$ of the total coastline European's extension [6], and about 160,000 nautical berths [7], Italy, like Greece and Croatia, represents one of the main representative countries of the nautical tourism in the Mediterranean Sea. The case of Italian regions can be considered representative of more cases as the one relative to the European countries around the Mediterranean Sea. In fact, Italian coasts, in the northern Mediterranean, have an intermediate length, between the longest as the Greece with about $13,500 \mathrm{~km}$ and the Spain with about 5,000 km not all in the Mediterranean Sea.

Despite its relevance, nautical tourism is an under-exploited research area [8]. Available sources and data on nautical tourism are limited and often in contradiction each with others. Moreover, quantitative research approaches are difficult within the available study resources [5]. 
It is relevant to note that nautical tourism has a stronger impact on regional economy and in particular on gross domestic product (GDP). It is important to specify spatial economic diffusion of economy linked to the nautical tourism at urban, regional and national levels [9].

In this context and with specific reference to Italian regional territories, this paper has the main objective to review in a critical way official sources of information about nautical tourism, linking demand with supply. The final aim is to represent the current situation of nautical tourism in the Italian regions.

Available databases and statistical analyses provide comparisons in terms of infrastructures, services and users of nautical tourism in Italy. Quantitative variables are classified in relation to transport nautical supply (infrastructures and services) and current demand. A first statistical analysis of available variables is developed. The elaborations constitute the first step of a transport planning process finalized to obtain specific models to plan nautical tourism at regional and national levels.

The paper, other than the Introduction, is composed of three sections. Section 2 describes the available data sources, collecting data and information on nautical tourism in Italy from different public authorities and private operators. Section 3 identifies quantitative variables related to infrastructures and services (transport supply) and to nautical tourism demand. Section 4 illustrates the first results of elaborations of the quantitative variables.

\section{DATA SOURCES}

In Italy, data on nautical tourism comes from maritime public authorities and private operators that collect information relative to nautical supply (infrastructures and services), boating demand, and their interactions. In the following sections, principal information about data sources from public authorities (Section 2.1) and private operators (Section 2.2) are reported. A final section reports a summary and a classification of available sources (Section 2.3).

\subsection{Data sources from public authorities}

Italian public authorities publish databases with information collected at national and regional levels.

\subsubsection{National authorities}

The Italian Ministry of Infrastructures and Transport (MIT) collects information deriving from port authorities according to national laws [7], [10].

MIT publishes an annual report with data and analyses on recreational boating. In this report, quantitative data are relative to:

- nautical infrastructures and services and, in particular, quantitative data describing each touristic port in terms of:

- berths;

- moorings and equipment;

- classes of boat length (<10 m; 10-24 m; > $24 \mathrm{~m})$;

- registered vessels classified for:

- type of propulsion (motorboats, sailboats);

- class of length $(<10 \mathrm{~m} ; 10-24 \mathrm{~m} ;>24 \mathrm{~m})$;

- users' licenses classified for authorized driving distance from the coast (limit to 12 nautical miles; no limits).

It is important to note that vessels shorter than $10 \mathrm{~m}$ are present in the ports but they are not registered; it happens because there is a lack of a legal obligation [7]. 


\subsubsection{Regional authorities}

Regional authorities collect information on nautical tourism. Some authorities have instituted regional observatories of tourism at regional level. These observatories realize specific surveys concerning nautical tourism. For instance, the Liguria region, in collaboration with Unioncamere Liguria and national institutes for touristic researches (Istituto Nazionale Ricerche Turistiche (IS.NA.R.T.)) have performed a survey on nautical tourism at regional level collecting information on the availability of touristic ports and statistical profiles of nautical users [11].

\subsection{Data sources from private operators}

\subsubsection{INGEMAR}

Ingegneria Marittima srl (INGEMAR) is an Italian company operating in the nautical tourism sector. The main specialization is the designing and construction of facilities for recreational boating. INGEMAR periodically publishes a report that describes characteristics of the marinas present in Italy. The annual reports collect data relative to infrastructures and services of Italian marinas [12]-[14]. Available information for each monitored touristic port concerning berths number, physical characteristics (length and depth) and renting rates.

\subsubsection{UCINA}

The Unione Nazionale dei Cantieri e delle Industrie Nautiche e Affini (UCINA) is an Italian association of recreational boating industries and companies operating in the nautical sector. The association promotes the development of nautical tourism in Italy. Among its activities, UCINA collects, elaborates and disseminates data concerning the industry of nautical tourism both in relation to the domestic and international markets. These data are published in an annual report that includes a market analysis [15], [16].

The UCINA's report collects data on the nautical industry (shipbuilding, access, and engines) and boating (infrastructures and services, nautical licenses). Available data and information on the ports are grouped by Italian regions. The report refers to the following categories of ports:

- marina, including ports entirely dedicated to boating;

- multi-purpose ports, comprehending nautical facilities which perform different functions (industrial, commercial and nautical);

- mooring points, including removable infrastructures used in certain periods of the year: this class includes different types of structures (docks and piers, equipped beaches and landing stages).

Multi-purpose ports represent about $60 \%$ of total Italian ports; the remaining $40 \%$ comprehends mooring points (30\%) and marinas (10\%) [16].

\subsubsection{CNA}

The Confederazione Nazionale dell'Artigianato e della Piccola e Media Impresa (CNA) represents companies and self-employed workers in Italy. These include small and medium companies operating in the nautical sector. The confederation publishes an annual report collecting data relative to national and international nautical markets. Some elaborations depict trends of the nautical market.

In relation to the purposes of this paper, the estimation of the unregistered nautical fleet and of small boating is relevant. In fact, according to the national legislation, the registration of recreational boats shorter than $10 \mathrm{~m}$ (defined as "boats") is not mandatory. For this reason, 
the available data relative to the consistency of these type of boats are approximate. The recreational boats, registered on a voluntary basis, belonging to this class amount to 56,000 units. By considering estimations of motor and sailing boats, the Italian fleet of small boats amounts about 418,000 units [17].

\subsubsection{Pagine Azzurre}

Pagine Azzurre is an online platform that provides information useful for boat users. The platform publishes information for recreational boating describing ports, coast, and the main coastal nautical and touristic services.

Pagine Azzurre gathers information on over 870 ports throughout the Italian coast. There are specific information about infrastructures and services available in each port (fuel distributor, water and electricity on the quay, etc.) and in the surrounding area (nautical workshops, hotels, restaurants, pharmacies and other information useful for boaters) [18].

\subsection{Synthesis of available sources}

Collected data can be classified in relation to transport subsystems: data relative to supply subsystem concerning information on nautical infrastructures and services; data relative to demand subsystem concerning information on nautical users. Table 1 reports a summary of available data, in relation to transport subsystems (demand and supply), deriving from selected sources.

Table 1: Available data from selected sources.

\begin{tabular}{|c|c|c|c|c|c|c|c|}
\hline & & & $\begin{array}{c}\text { MIT } \\
{[7]}\end{array}$ & $\begin{array}{c}\text { INGEMAR } \\
{[13]}\end{array}$ & $\begin{array}{c}\text { UCINA } \\
{[16]}\end{array}$ & $\begin{array}{l}\text { CNA } \\
{[17]}\end{array}$ & $\begin{array}{c}\text { Pagine } \\
\text { Azzurre } \\
{[18]}\end{array}$ \\
\hline \multirow{8}{*}{ 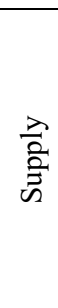 } & \multirow{3}{*}{$\begin{array}{l}\text { Quantity of nautical } \\
\text { berth for }\end{array}$} & Type of port & $\mathrm{X}$ & & $\mathrm{X}$ & & \multirow{3}{*}{$\mathrm{X}$} \\
\hline & & Type of boat & $X$ & $\mathrm{X}$ & & & \\
\hline & & Type of user & & $\mathrm{X}$ & & & \\
\hline & Berth's depth (m) & & & $\mathrm{X}$ & & & \multirow[t]{4}{*}{$\mathrm{X}$} \\
\hline & Hauling (max tons) & & & $X$ & & & \\
\hline & Berth's rates & & & $X$ & & & \\
\hline & Services equipment & & $\mathrm{X}$ & & & & \\
\hline & Ships production & & & & $\mathrm{X}$ & $\mathrm{X}$ & \\
\hline \multirow{3}{*}{ 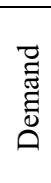 } & \multicolumn{2}{|c|}{$\begin{array}{l}\text { Nautical licenses for allowed } \\
\text { navigation distance }\end{array}$} & $\mathrm{X}$ & & $\mathrm{X}$ & & \\
\hline & \multirow[b]{2}{*}{ Boats for } & Length (m) & $\mathrm{X}$ & & $\mathrm{X}$ & & \\
\hline & & $\begin{array}{l}\text { Type of } \\
\text { engine }\end{array}$ & & & $\mathrm{X}$ & & \\
\hline
\end{tabular}

\section{QUANTITATIVE BASIC VARIABLES}

Starting from available information obtainable from selected recalled sources, a set of quantitative basic variables can be identified in order to provide a synthetic description of the nautical tourism characteristics in Italy respect to distribution of population among regions. Section 3.1 reports socioeconomics and territorial variables that describe the regional context in which nautical tourism operates. Section 3.2 illustrates the supply and demand variables of Italian nautical tourism with a specific reference to available information deriving from national authorities. 


\subsection{Socioeconomics and territorial variables}

Selected socioeconomics and territorial variables are collected for each Italian region and for the regions bathed by the sea.

Defined with $R$ the full set of Italian regions, some specific subsets can be considered:

- $R T$ the set of regions bathed by the sea;

- $C N$ the set of $R T$ located in the centre-north of Italy (Liguria, Tuscany, Lazio, Marche, Emilia Romagna, Veneto, Friuli Venezia Giulia (Friuli VG));

- SI the set of RT located in the south of Italy (Campania, Calabria, Puglia, Molise, Abruzzo, Sardinia, Sicily).

Note that:

$R T \subset R$

$R T=C N \cup S I$.

For each Italian region $r(r \in R)$ it is possible to consider:

- $\operatorname{pop}_{r}$, the population in the region $r$;

- $i n c_{r}$, the average income of the population in the region $\mathrm{r}$;

- $k m_{r}$, the coastal extension of the region $r$, expressed in kilometres $(\mathrm{km})$.

3.2 Supply and demand variables

By considering the subsets identified in Section 3.1, the following supply and demand variables are analysed starting from the MIT database [7]:

- $l_{r}$, total number of nautical licenses in the region $r$; the variable is available in relation to allowed navigation distance (within 12 nautical miles; without limitations);

- $b_{r}$, total number of nautical boats registered in the region $r$; the variable is available in relation to:

- boat length $(<10 \mathrm{~m} ; 10-24 \mathrm{~m} ;>24 \mathrm{~m})$;

- typology of engine (motorboats; sailing boats);

- $n b_{r}$, total number of nautical berths in the $r$ with

- $n b_{r} \neq 0$ for $r \in R T$;

- $n b_{r}=\emptyset$ for the others;

the variable is available in relation to:

- typology of port (marina, multi-purpose ports; mooring points);

- mooring berth capacity measured in terms of boats' length ( $<10 \mathrm{~m} ; 10-24 \mathrm{~m} ;>24 \mathrm{~m})$.

\section{AGGREGATE SOCIAL INDICATORS}

Elaborations of available data derived from selected sources, provide aggregate social indicators of nautical tourism at regional level. Starting from a selection of quantitative variables defined in Section 3.2, the aggregate indicators relative to supply (Section 4.1) and demand (Section 4.2) subsystems of the Italian regions are calculated.

\subsection{Supply indicators}

Selected variables linking supply and socioeconomic data are elaborated in order to obtain aggregate indicators: 
- availability of nautical berths for a unit of residential population

$$
A N B_{r}=\frac{n b_{r}}{p o p_{r}} \quad \forall r \in R T
$$

- average availability of nautical berths for a unit of residential population in relation to the regional subsets defined in Section $3.1(R T, C N, S I)$

$$
\begin{aligned}
& \overline{A N B}_{R T}=\frac{1}{N_{R T}} \sum_{\mathrm{r} \in R T} A N B_{r}, \\
& \overline{A N B}_{C N}=\frac{1}{N_{C N}} \sum_{\mathrm{r} \in C N} A N B_{r}, \\
& \overline{A N B}_{S I}=\frac{1}{N_{S I}} \sum_{\mathrm{r} \in S I} A N B_{r},
\end{aligned}
$$

where $N_{R T}, N_{C N}$ and $N_{S I}$ are the numbers of elements of each subset;

- percentage of nautical berths respect to average values referred to each subset defined in Section 3.1

$$
\begin{gathered}
P N B_{R T, r}=\frac{A N B_{\mathrm{r}}}{\overline{\overline{A N B}}_{R T}} \quad \forall r \in R T, \\
P N B_{C N, r}=\frac{A N B_{\mathrm{r}}}{\overline{A N B}_{C N}} \quad \forall r \in C N, \\
P N B_{S I, r}=\frac{A N B_{\mathrm{r}}}{\overline{A N B}_{S I}} \quad \forall r \in S I .
\end{gathered}
$$

Table 2 reports values of the supply indicators formulated in eqns (1)-(7). Note that the highest values are relative to regions located in northern territories. For these regions, the average quantity of nautical berths per inhabitants $\overline{A N B}_{C N}$ is higher than the national average by $24 \%$. By considering this set, two regions (Liguria and Friuli VG) register a number of nautical berths per inhabitants that is higher than other regions, with values about three times than the Italian average. Liguria region registers the highest value of nautical berths quantity of Italy. Among southern regions, Sardinia emerges with values approximately double compared to the average Italian value. The data at regional level can be processed with specific model as Data Envelopment Analysis (DEA) [20], [21] to analyse the efficiency of the aggregated territory (regions) respect to the nautical tourism. From these first results, it emerges the existence of two outlier regions: Liguria and Friuli VG. These two regions have nautical berths four times the average Italian level. By considering that the average income of these regions is approximately equal to the other regions of the north Italy, it needs to investigate other factors. The more relevant is the geographical definitions. In fact, Liguria has a surface of $5,416.21 \mathrm{~km}^{2}$ and then the touristic ports have an attraction area covering the near Piedmont and part of Lombardy regions.

\subsection{Demand indicators}

Selected variables related to demand subsystem are elaborated in order to obtain two sets of aggregate demand indicators. 
Table 2: Supply indicators for the Italian regions eqns (1)-(7). Nautical berths per 1,000 units of residential population.

\begin{tabular}{|c|c|c|c|c|}
\hline & Regions & $A N B_{r}$ & $P N B_{C N, r}$ & $P N B_{R T, r}$ \\
\hline \multirow{7}{*}{ z } & Liguria & 16.21 & 2.68 & 3.48 \\
\hline & Tuscany & 5.02 & 0.83 & 1.08 \\
\hline & Lazio & 1.46 & 0.24 & 0.31 \\
\hline & Marche & 3.46 & 0.57 & 0.74 \\
\hline & Emilia Romagna & 1.21 & 0.20 & 0.26 \\
\hline & Veneto & 1.33 & 0.22 & 0.29 \\
\hline & Friuli VG & 13.71 & 2.26 & 2.95 \\
\hline \multicolumn{5}{|c|}{$\overline{\mathrm{ANB}}_{C N}=6.06$} \\
\hline & & $A N B_{r}$ & $P N B_{S I, r}$ & $P N B_{R T, r}$ \\
\hline \multirow{8}{*}{$\bar{\omega}$} & Basilicata & 1.81 & 0.53 & 0.39 \\
\hline & Campania & 2.52 & 0.74 & 0.54 \\
\hline & Calabria & 2.36 & 0.69 & 0.51 \\
\hline & Puglia & 3.05 & 0.89 & 0.66 \\
\hline & Molise & 1.89 & 0.55 & 0.41 \\
\hline & Abruzzo & 2.04 & 0.60 & 0.44 \\
\hline & Sardinia & 10.63 & 3.10 & 2.28 \\
\hline & Sicily & 3.10 & 0.91 & 0.67 \\
\hline \multicolumn{5}{|c|}{$\overline{A N B}_{S I}=3.43$} \\
\hline \multicolumn{5}{|c|}{$\overline{A N B}_{R T}=4.65$} \\
\hline
\end{tabular}

A first set of demand indicators comprehends:

- nautical licenses for a unit of residential population for each region

$$
N L_{r}=\frac{l_{r}}{p o p_{r}} \quad \forall r \in R T
$$

- average availability of nautical licences for a unit of residential population in relation to the regional subsets defined in Section 3.1 (RT, CN, SI)

$$
\begin{aligned}
& \overline{N L}_{R T}=\frac{1}{N_{R T}} \sum_{\mathrm{r} \in R T} N L_{r}, \\
& \overline{N L}_{C N}=\frac{1}{N_{C N}} \sum_{\mathrm{r} \in C N} N L_{r}, \\
& \overline{N L}_{S I}=\frac{1}{N_{S I}} \sum_{\mathrm{r} \in S I} N L_{r} ;
\end{aligned}
$$

- percentage of nautical licenses for a unit of residential population respect to average values referred to each subset defined in Section 3.1

$$
P N L_{R T, r}=\frac{N L_{\mathrm{r}}}{\overline{N L}_{R T}} \quad \forall r \in R T,
$$




$$
\begin{array}{ll}
P N L_{S I, r}=\frac{N L_{\mathrm{r}}}{\overline{N L_{S I}}} \quad \forall r \in S I, \\
P N L_{S I, r}=\frac{N L_{\mathrm{r}}}{\overline{N L_{S I}}} \quad \forall r \in S I .
\end{array}
$$

Table 3 reports values of indicators formulated in eqns (8)-(14) and calculated for Italian regions referring to the regional sets introduced in Section 3.1.

Table 3: Demand indicators for the Italian regions eqns (8)-(14). Nautical licenses per 1,000 units of residential population.

\begin{tabular}{cccc}
\hline \multicolumn{1}{c}{ Regions } & $N L_{r}$ & $P N L_{C N, r}$ & $P N L_{R T, r}$ \\
\hline Liguria & 5.63 & 3.71 & 5.61 \\
Tuscany & 0.83 & 0.55 & 0.83 \\
Lazio & 0.59 & 0.39 & 0.59 \\
Marche & 0.78 & 0.51 & 0.77 \\
Emilia Romagna & 0.56 & 0.37 & 0.56 \\
Veneto & 0.45 & 0.30 & 0.45 \\
Friuli VG & 1.78 & 1.17 & 1.77 \\
\hline \multicolumn{5}{c}{$N L_{r}$} & $P N L_{S I, r}$ & $P N L_{R T, r}$ \\
\hline \multicolumn{5}{c}{$\overline{N L}_{C N}=1.52$} \\
\hline Basilicata & 0.17 & 0.31 & 0.17 \\
Campania & 0.57 & 1.02 & 0.56 \\
Calabria & 0.45 & 0.81 & 0.45 \\
Puglia & 0.36 & 0.65 & 0.36 \\
Molise & 0.14 & 0.24 & 0.13 \\
Abruzzo & 0.40 & 0.72 & 0.40 \\
Sardinia & 1.49 & 2.69 & 1.49 \\
Sicily & 0.86 & 1.55 & 0.86 \\
\hline \multicolumn{5}{c}{$N L_{S I}=0.56$} \\
\hline
\end{tabular}

A second set of demand indicators comprehends:

- boats for a unit of residential population

$$
B P_{r}=\frac{b_{r}}{p o p_{r}} \quad \forall r \in R T ;
$$

- average availability of nautical boats for a unit of residential population in relation to the regional subsets defined in Section $3.1(R T, C N, S I)$

$$
\begin{aligned}
& \overline{B P}_{R T}=\frac{1}{N_{R T}} \sum_{\mathrm{r} \in R T} B P_{r}, \\
& \overline{B P}_{C N}=\frac{1}{N_{C N}} \sum_{\mathrm{r} \in C N} B P_{r},
\end{aligned}
$$




$$
\overline{B P}_{S I}=\frac{1}{N_{S I}} \sum_{\mathrm{r} \in S I} B P_{r} ;
$$

- percentage of nautical boats for a unit of residential population respect to average values referred to each subset defined in Section 3.1

$$
\begin{gathered}
P B P_{R T, r}=\frac{B P_{r}}{\overline{B P}_{R T}} \quad \forall r \in R T, \\
P B P_{C N, r}=\frac{B P_{r}}{\overline{B P}_{C N}} \quad \forall r \in C N, \\
P B P_{S I, r}=\frac{B P_{r}}{\overline{B P}_{S I}} \quad \forall r \in S I .
\end{gathered}
$$

Table 4 reports values of the second set of demand indicators formulated in eqns (15)(21) and calculated for Italian regions referring to the regional sets introduced in Section 3.1.

Table 4: Demand indicators for the Italian regions eqns (15)-(21). Boats per 1,000 units of residential population.

\begin{tabular}{lccc}
\hline & $B P_{r}$ & $P B P_{C N, r}$ & $P B P_{R T, r}$ \\
\hline Regions & 11.94 & 0.82 & 4.44 \\
Liguria & 2.82 & 0.19 & 1.05 \\
Tuscany & 2.01 & 0.14 & 0.75 \\
Lazio & 2.07 & 0.14 & 0.77 \\
Marche & 1.10 & 0.08 & 0.41 \\
Emilia Romagna & 1.33 & 0.09 & 0.49 \\
Veneto & 3.38 & 0.23 & 1.26 \\
Friuli VG & $\overline{B P}_{C N}=3.52$ & & \\
\hline \multicolumn{5}{c}{$B P_{r}$} & $P B P_{S I, r}$ & $P B P_{R T, r}$ \\
\hline \multicolumn{5}{c}{1.71} & 0.39 & 0.64 \\
\hline Basilicata & 0.02 & 0.00 & 0.01 \\
Campania & 7.70 & 1.75 & 2.86 \\
Calabria & 1.71 & 0.39 & 0.64 \\
Puglia & 0.77 & 0.17 & 0.28 \\
Molise & 0.20 & 0.05 & 0.08 \\
Abruzzo & 0.66 & 0.15 & 0.25 \\
Sardinia & 2.91 & 0.66 & 1.08 \\
Sicily & $\overline{B P}_{S I}=1.96$ \\
\hline \multicolumn{5}{c}{$=2.69$} \\
\hline
\end{tabular}

A third set of demand indicators comprehends:

- boats per nautical licenses

$$
B L_{r}=\frac{b_{r}}{l_{r}} \quad \forall r \in R T
$$


- average availability of nautical boats per nautical licenses in relation to the regional subsets defined in Section $3.1(R T, C N, S I)$

$$
\begin{gathered}
\overline{B L}_{R T}=\frac{1}{N_{R T}} \sum_{\mathrm{r} \in R T} B L_{r}, \\
\overline{B L}_{C N}=\frac{1}{N_{C N}} \sum_{\mathrm{r} \in C N} B L_{r}, \\
\overline{B L}_{S I}=\frac{1}{N_{S I}} \sum_{\mathrm{r} \in S I} B L_{r}
\end{gathered}
$$

- percentage of nautical boats per nautical licence respect to average values referred to each subset defined in Section 3.1

$$
\begin{gathered}
P B L_{R T, r}=\frac{B L_{r}}{\overline{B L}_{R T}} \quad \forall r \in R T, \\
P B L_{C N, r}=\frac{B L_{r}}{\overline{B L}_{C N}} \quad \forall r \in C N, \\
P B L_{S I, r}=\frac{B L_{r}}{\overline{B \bar{L}_{S I}}} \quad \forall r \in S I .
\end{gathered}
$$

\begin{tabular}{|c|c|c|c|c|}
\hline & Regions & $B L_{r}$ & $P B L_{C N, r}$ & $P B L_{R T, r}$ \\
\hline \multirow{7}{*}{ u } & Liguria & 2.11 & 0.16 & 0.30 \\
\hline & Tuscany & 3.12 & 0.23 & 0.44 \\
\hline & Lazio & 6.00 & 0.45 & 0.85 \\
\hline & Marche & 72.10 & 5.36 & 10.18 \\
\hline & Emilia Romagna & 8.01 & 0.60 & 1.13 \\
\hline & Veneto & 1.83 & 0.14 & 0.26 \\
\hline & Friuli VG & 0.95 & 0.07 & 0.13 \\
\hline \multicolumn{5}{|c|}{$\overline{B L}_{C N}=13.44$} \\
\hline & & $B L_{r}$ & $P B L_{S I, r}$ & $P B L_{R T, r}$ \\
\hline \multirow{8}{*}{$\bar{\omega}$} & Basilicata & 1.03 & 0.68 & 0.13 \\
\hline & Campania & 2.73 & 1.80 & 0.35 \\
\hline & Calabria & 1.03 & 0.68 & 0.13 \\
\hline & Puglia & 1.93 & 1.27 & 0.25 \\
\hline & Molise & 1.33 & 0.88 & 0.17 \\
\hline & Abruzzo & 1.18 & 0.78 & 0.15 \\
\hline & Sardinia & 1.80 & 1.19 & 0.23 \\
\hline & Sicily & 1.10 & 0.73 & 0.14 \\
\hline \multicolumn{5}{|c|}{$\overline{B L}_{S I}=1.52$} \\
\hline & & $T=7$ & & \\
\hline
\end{tabular}

Table 5 reports values of the third set of indicators formulated in eqns (22)-(28) and calculated for Italian regions referring to the regional sets introduced in Section 3.1.

Table 5: Demand indicators for the Italian regions eqns (22)-(28). Boats per nautical licenses. 
Note that, like the case of supply indexes, the first set of demand indexes shows two regions (Liguria and Friuli VG) with values higher than the average values referred to the selected subsets.

By considering the second set of demand indicators, the regions belonging to the set $C N$ have average values higher than the other regions. These regions register an average number of boats per unit of residential population higher than the national average value and four times respect to the SI value. The value indicator for Liguria region is more than triple respect to $C N$ average value. Regions belonging to $S I$ set, excluding Campania and Sicily, register about less than one unit of boat per 1,000 units of residential population (Table 4).

By considering the third set of demand indicators, the regions belonging to the set $C N$ have average values higher than the other regions. These regions register a number of boats per nautical licenses double respect to the national average value and ten times respect to the SI value. Marche region, with 72 boats per nautical licenses represents an outlier. Regions belonging to SI set register about a unit of boat for a unit of nautical licence (Table 5).

\section{CONCLUSIVE REMARKS}

The paper presents a first step of a research on nautical tourism and its disaggregation for Italian regions. The basic social variables are crucial for the development of demand/supply analyses. The available sources of information available are often lacking and uneven among them. Despite the importance of the sector, it would be necessary to investigate the related phenomena.

Results of data analyses show differences among Italian touristic regions and in particular divergences between north and south regions in terms of infrastructures for nautical tourism and in terms of basic demand variables as nautical licenses and boats. The basic indicators can be useful in a transportation planning process concerning nautical tourism and mutual relationships with surrounding port areas. As a basic projection, Table 6 reports some simulated scenarios for the set SI under different assumptions. The current values of the indicator $n b_{r}$ are simulated assuming the indicator $\overline{A N B}_{R T}=4.65$ (simulated scenario $R T$ ) or the indicator $\overline{A N B}_{C N}=6.06$ (simulated scenario $C N$ ). Obtained results show the lack of nautical berths in the southern regions, with the singularity of Sardinia that needs a precise attention. As first evidence, we can consider from one side the average income in the southern regions respect to the one in the northern; from another side the work in progress in the south respect to the increasing of berth that cannot be actualised in the MIT data.

Table 6: Simulated scenarios. Projected nautical berths.

\begin{tabular}{lcccc}
\hline & & Current scenario & $\begin{array}{c}\text { Simulated scenario } \\
R T^{*}\end{array}$ & $\begin{array}{c}\text { Simulated scenario } \\
C N^{* *}\end{array}$ \\
\hline Regions & $p o p_{r}{ }^{*} 10^{6}$ & $n b_{r}{ }^{*} 10^{3}$ & $n b_{r}{ }^{*} 10^{3}$ & $n b_{r}{ }^{*} 10^{3}$ \\
\hline Basilicata & 0.57 & 1.03 & 2.65 & 3.45 \\
Campania & 5.84 & 14.74 & 27.17 & 35.36 \\
Calabria & 1.97 & 4.63 & 9.14 & 11.90 \\
Puglia & 4.06 & 12.41 & 18.91 & 24.61 \\
Molise & 0.31 & 0.59 & 1.44 & 1.88 \\
Abruzzo & 1.32 & 2.70 & 6.15 & 8.01 \\
Sardinia & 1.65 & 17.58 & 7.69 & 10.01 \\
Sicily & 5.06 & 15.69 & 23.53 & 30.62 \\
\hline
\end{tabular}

*By projecting the current scenario's values with the indicator $\overline{\mathrm{ANB}}_{R T}=4.65$

**By projecting the current scenario's values with the indicator $\overline{A N B}_{C N}=6.06$ 


\section{ACKNOWLEDGEMENTS}

The authors would like to thank MIT (Dipartimento per le Infrastrutture, i Sistemi Informativi e Statistici) and INGEMAR srl for precious data and information provided in this research.

\section{REFERENCES}

[1] Russo, F., Musolino, G. \& Assumma, V., Competition between ro-ro and lo-lo services in short sea shipping market: The case of Mediterranean countries. Research in Transportation Business and Management, 19, pp. 27-33, 2016.

[2] Russo, F., Musolino, G. \& Assumma, V., An integrated procedure to estimate demand flows of maritime container transport at international scale. International Journal of Shipping and Transport Logistics, 6(2), pp. 112-132, 2014.

[3] Diakomihalis, M.N., Greek maritime tourism: Evolution, structures and prospects. Research in Transportation Economics. 21, pp. 419-455, 2007.

[4] European Commission, Coastal and maritime tourism, 2019. https://ec.europa.eu/ maritimeaffairs/policy/coastal_tourism_en. Accessed on: Jun. 2019.

[5] European Commission, Directorate-General for Maritime Affairs and Fisheries, Assessment of the impact of business development improvements around nautical tourism, 2017. DOI: 10.2771/26485.

[6] Confindustria Nautica (UCINA), La nautica in cifre. Trend di mercato per l'anno 2018. www.lanauticaincifre.it/pubblicazioni/. Accessed on: Jun. 2019.

[7] Ministero delle Infrastrutture e dei Trasporti (MIT), Diporto Nautico in Italia - Anno 2016. www.mit.gov.it/diporto-nautico-italia-2016. Accessed on: May 2019.

[8] González, Y.E.L., Ledesma, d.L. \& León González, C.J., European nautical tourists: Exploring destination image perceptions. Tourism and Hospitality Management, 21(1), pp. 33-49, 2015.

[9] Russo, F. \& Musolino, G., A unifying modelling framework to simulate the spatial economic transport interaction process at urban and national scales. Journal of Transport Geography, 24, pp. 189-197, 2012.

[10] Decreto Ministeriale N. 146 del 29/07/2008. Ministero delle infrastrutture e dei Trasporti. Regolamento di attuazione dell'articolo 65 del decreto legislativo 18 luglio 2005, n. 171.

[11] Istituto Nazionale Ricerche Turistiche (IS.NA.R.T.), Il Turismo Nautico Nella Regione Liguria. Osservatorio turistico della Liguria, 2017. www.regione.liguria.it/components/com_publiccompetitions/includes/download.php ?id=11068:indagine-sul-turismo-nautico-anno-2016.pdf. Accessed on: Jun. 2019.

[12] Ingegneria Marittima (INGEMAR), 194 marina d'Italia, Parziale estratto in collaborazione con Barche a Motore e Il Giornale della Vela, 2011.

[13] Ingegneria Marittima (INGEMAR), Marina d'Italia 2017, Parziale estratto in collaborazione con Barche a Motore e Il Giornale della Vela, 2017. www.ali6.org/\#archivio. Accessed on: May 2019.

[14] Ingegneria Marittima (INGEMAR), Presentazione INGEMAR, 2018. www.ingemar.it/it/chi-siamo. Accessed on: May 2019.

[15] Confindustria Nautica (UCINA), Chi siamo, 2018. https://ucina.net/chi-siamo/. Accessed on: Jun. 2019.

[16] Confindustria Nautica (UCINA), La nautica in cifre - analisi del mercato per l'anno 2016, 2017. www.lanauticaincifre.it/pubblicazioni/. Accessed on: Jun. 2019. 
[17] Confederazione Nazionale dell'Artigianato e della Piccola e Media Impresa (CNA), Dinamiche e prospettive di mercato della filiera nautica da diporto. Quinta edizione, 2017. www.cna.it/centro-studi/notizie/2017dinamiche-e-prospettive-di-mercatodella-filiera-nautica-da-diporto\#.WvAkloiFPcs. Accessed on: May 2019.

[18] PagineAzzurre.it, 2018. Accessed on: Jun. 2019.

[19] Musolino, G., Rindone, C. \& Vitetta, A., Passengers and freight mobility with electric vehicles: A methodology to plan green transport and logistic services near port areas. Transportation Research Procedia, 37, pp. 393-400, 2019.

[20] Russo, F. \& Rindone, C., Data Envelopment Analysis (DEA) for evacuation planning. WIT Transactions on Information and Communication Technologies, vol. 43, WIT Press: Southampton and Boston, pp. PI455-PI467, 2010.

[21] Russo, F. \& Rindone, C., Container maritime transport on an international scale: Data envelopment analysis for transhipment port. WIT Transactions on Ecology and the Environment, vol. 150, WIT Press: Southampton and Boston, pp. 831-843, 2011. 